\title{
Risk Değerlendirmesinde Bulanık Fine-Kinney Yöntemi ve Uygulaması
}

\author{
Fuzzy Fine - Kinney Approach in Risk Assessment and an Application
}

\author{
Murat OTURAKÇI, Cansu DAĞSUYU
}

\begin{abstract}
ÖZET
Bu çalışmada risk değerlendirme metotları arasında sıklıkla kullanılan ancak literatür açısından yeteri kadar kaynağı bulunmayan Fine - Kinney Yöntemi için bulanık mantık çerçevesinde yeni bir yaklaşım geliştirilmiştir. Klasik yöntem içerisinde kullanılan olasılık, frekans ve şiddet parametreleri girdi; risk skoru çıktı olarak kabul edilmiş ve bu ölçekler üçgen üyelik fonksiyonlarına bağlı yeni ölçeklere dönüștürülmüştür. Klasik ve Bulanık Fine - Kinney metotları inşaat sektöründe hizmet veren orta ölçekli bir firmanın yapımını üstlendiği bir yapı merkezi inşaatında belirlenen tehlikelere uygulanarak karşılaştırılmıştır. Böylece her bir tehlike için hesaplanan risk skoru, bulanık mantık çerçevesinde tekrar hesaplanmış ve sonuçlar karşılaştırılmıştır. Ortaya konan Bulanık Fine - Kinney Yöntemi'nin Klasik yönteme göre sonuçlara hassasiyet kazandırdığı görülmüştür. Ayrıca tehlikelerin öncelik sıralamalarının değişmesiyle birlikte bu tehlikelerin sınıflarının da değiştiği gözlenmiştir.
\end{abstract}

Anahtar Kelimeler: Fine - Kinney Yöntemi, Bulanık Fine - Kinney Yöntemi, Risk Değerlendirme Yöntemleri, Risk Skoru

\section{ABSTRACT}

In this study, a new approach with fuzzy logic frame has been developed for Fine - Kinney Method, which is a frequently used method among risk assessment methods and has lack of literature. Probability, Frequency and Intensity parameters are defined as inputs; risk score is defined as output from classic method and new scales has been formed depends on triangular membership functions. Classic and Fuzzy Fine - Kinney Methods are compared by applying them to the identified hazards in construction center which is constructed by a medium size firm. Thus, all the risk scores, which are calculated for each hazard, are recalculated again and results are compared. New approach, Fuzzy Fine - Kinney, is brought sensitivity to results when it is compared to classic method. Also, Fuzzy Fine - Kinney Method is changed risk classes of hazards and differentiated prioritizations of hazards.

Keywords: Fine - Kinney Method, Fuzzy Fine - Kinney Method, Risk Assessment, Risk Score

Yrd. Doç. Dr. Murat OTURAKÇı - Adana Bilim ve Teknoloji Üniversitesi, Mühendislik Fakültesi, Adana, Türkiye

Assist. Prof. Murat OTURAKCI - Adana Science and Technology University, Faculty of Engineering, Adana, Turkey

moturakci@adanabtu.edu.tr

Dr. Cansu DAĞSUYU - Çukurova Üniversitesi, Mühendislik-Mimarlık Fakültesi, Adana, Türkiye

Dr. Cansu DAGSUYU - Cukurova University, The Faculty of Engneering \& Architecture, Adana, Turkey

cdagsuyu@cuedu.tr 


\section{GİRİ̧̧}

İş sağlığı ve güvenliği çalışmalarına verilen önem her geçen gün artmaktadır. Yasal zorunluluklar ile birlikte gelişen ve değişen teknolojinin yaptırımları, işletmelerde daha güvenli bir ortamda çalışılması için gerekli zeminin hazırlanmasını gerektirmektedir. İşletmelerde hem işçinin, hem de üretimin veya hizmetin güvenli ve sağlıklı koşullarda birlikte yürütülmesi iş sağlığı ve güvenliği kavramının tümünü oluşturmaktadır. 4857 sayılı İş Kanunu ve 6331 sayılı İş Sağlığı ve Güvenliği Kanunu ilgili maddeleri uyarınca işverenlere, işyerinde var olan ya da dışarıdan gelebilecek tehlikelerin belirlenmesi ve bertaraf edilmesi için risk değerlendirmesi zorunlu hale getirilmiştir [1]. İlgili kanunlar ile işyerlerinde sürekli iyileştirmenin sağlanması amacıyla risk değerlendirmesi çalışmalarının güncel tutulması ile birlikte risk değerlendirme çalışmalarının işyerlerinin tehlike sınıflarına göre periyodik olarak yenilenmesi zorunluluğu da beraberinde getirilmiştir. Bu yasal zorunluluk sebebiyle işletmeler, risk değerlendirme çalışmalarına verdikleri önemi arttırmış, işletmenin türüne göre kendilerine en uygun olan risk değerlendirme metodunu uygulamaya başlamışlardır. Doğru risk değerlendirme metodunun işletmelere uygulanması hayati önem taşıdığından konu üzerine yapılan çalışmaların sayısı da gün geçtikçe artma eğilimi göstermektedir.

Risk analiz yöntemleri kantitatif ve kalitatif yöntemler olmak üzere iki gruba ayrılır. Kantitatif risk analizi, riski hesaplarken sayısal yöntemlere başvurur. Kalitatif risk analizinde tehdidin olma olasılığı, tehdidin etkisi gibi değerlere sayısal değerler verilir ve bu değerler matematiksel ve mantıksal metotlar ile proses edilip risk değeri bulunur [2]. Risk Haritası, Başlangıç Tehlike Analizi, İş Güvenlik Analizi, Çeklist Kullanılarak Birincil Risk Analizi, Birincil Risk Analizi, Risk Değerlendirme Karar Matris Metodolojisi (L tipi ve X tipi Matris), Tehlike ve İşletilebilme Çalışması Metodolojisi, Hata Ağacı Analizi Metodolojisi, Olası Hata Türleri ve Etki Analizi Metodolojisi, Olay Ağacı Analizi, Neden- Sonuç Analizi ve Fine-Kinney Metodu başlıca kullanılan risk analiz metodlarındandır.

Risk analiz yöntemleri her ne kadar iki ana gruba ayrilmış olsa da uygulama adımları genel olarak benzerlik göstermektedir. Tüm risk analiz yöntemlerinde öncelikle tehlikeler tanımlanmakta ve risk analiz yönteminde bulunan parametrelere göre puanlanma yapılmaktadır. Risk analizi ile mevcut tehlikelerin puanlandırılmasının ardından tehlikelerin önceliklendirilmesi ve/veya sınıflandırılması yapılarak tehlikelerin mümkünse ortadan kaldırılması veya öncelik ve tehlike sınıfının azaltılması hedeflenmektedir. Uygulama alanı çok geniş olan risk analizi ile ilgili literatürde birçok sektör üzerinde yapılmış çokça çalışma bulunmaktadır. 2010 yılında Bonfant ve arkadaşları hata türleri ve etkileri analiz yöntemini kullanarak bir hastanenin diyaliz ünitesinde klinik risk analizini gerçekleştirmişlerdir. Yapılan değerlendirme ile önceliklendirme matrisinde değişiklik yapılarak aksiyon süreleri \%8.6 düzeyinde düşürülmüştür [3]. 2015 yılında Herrera ve arkadaşları tarafından Tehlike ve İşletilebilme Çalışması Metodolojisi kullanılarak biyofarmasötik endüstrisindeki bir işletmenin protein üretimindeki riskleri değerlendirilmiştir[4]. 2013 yılında Şenel ve Şenel yedi yıllık kaza istatistiklerinden yola çıkarak trafikte risk faktörleri ve bu risk faktörlerinin risk derecelerinin belirlenmesi amaçlayarak hata ağaç analizi metodolojisi kullanmış, belirlenen risk faktörleri ve birbirleri ile etkileşim dereceleri üzerinden ana olay olarak belirlenen trafik kazasının her bir hata türü için oluşma olasılığı ortaya koymuşlardır [5]. 2015 yılında Topaloğlu ve arkadaşları Yüksek Fırınların İşletilmesinde Risk Değerlendirilmesi için L tipi matris yöntemini kullanarak meydana gelen kazaların sebeplerini araştırmış iş kazalarında kazanın ana nedenleri ile tali nedenleri araştırılmış ve kayıt altına alınmıştır, düzeltici ve önleyici faaliyetler belirlenmiş ve yerine getirilip getirilmediği araştırılmıştır [6]. Literatürden seçilen bu örnekler dışında birçok risk analiz metodu ile birlikte farklı sektörlerde uygulamaları risk analizi yöntemlerinin çeşitliliği ve önemini gözler önüne sermektedir $[7,8,9]$.

Risk analiz yöntemlerinde tehlikelerin puanlandırılırken olasılık, şiddet, frekans, tespit edilebilirlik gibi pek çok parametre kullanılabilmektedir. Kullanılan parametreler, ilgili risk analiz yöntemine göre farklılık göstermekte ve çeşitli parametre skalaları oluşturulmaktadır. Oluşturulan bu skalalarda tehlikenin parametreye göre puanlandırılması risk analizini yapan uzmanın geçmiş iş kazası verilerini yorumlamasına göre değişkenlik gösterebilmektedir. Örneğin Fine-Kinney risk analiz yönteminde bulunan 'frekans' parametresine ait skalada tehlike 'oldukça seyrek' oluşuyorsa '0.5'; 'seyrek' oluşuyorsa' ' 1 '; 'nadir' oluşuyorsa '2'; ' ara sıra' oluşuyorsa '3'; 'sıklıkla' oluşuyorsa '6'; 'sürekli' oluşuyorsa '10' değerini almaktadır. Oluşan bir tehlikeyi bir uzman seyrek olarak değerlendirirken bir başka uzman nadir olarak değerlendirebilmektedir. Risk analizini yapan ekipte bulunan uzman kişilerin deneyimine göre değişebilen bu skalalar, analiz sonucunda ortaya çıkan tehlikenin sinıflandırmasında farklılık ve tutarsızlık yaratabilmekte, hayati önem taşıyan bir tehlike göz ardı edilebilmektedir.

$\mathrm{Bu}$ farklılıkları en aza indirgemek için risk analiz yöntemlerinde bulanık mantık yaklaşımı kullanımı gittikçe artan bir yöntem olarak karşımıza çıkmaktadır. Literatürde bulanık mantık yaklaşımının entegre edildiği pek çok risk analizi çalışması bulunmaktadır. Özellikle hata türleri ve etkileri analizi yöntemi üzerinde bulanık mantık anlayışı entegre edilmeye çalışılmıştır. Kumru ve Kumru (2010), bulanık mantık esaslı hata türü ve etkileri analizinin (HTEA) bir kamu hastanesinin satın alma sürecinin iyileş- 
tirilmesindeki uygulaması ele almış, belirledikleri 28 adet hata türünü önceliklendirerek çalışmalarını bulanık HTEA yaklaşımının yönetim süreçlerinde nassıl yararlı olabileceğine dair sonuçlar çıkarmışlardır [10]. Kahraman ve arkadaşları (2014), HTEA yöntemini kullanarak sağlık endüstrisindeki problemleri bulanık if-then kuralları ile kategorize etmiş ve uygulama örneğine çalışmalarında yer vermiştir [11]. Özfirat (2014), madencilik sektöründe yaptığı bir uygulama HTEA' da kullanılan kaza olasılığı, şiddeti ve farkedilebilirliği kriterleri bulanık analitik hiyerarşi süreci (BAHS) yöntemlerinden biri olan bulanık önceliklendirme metodu ile ele almıştır [12]. Literatürde bulanık mantık temelli HTEA yöntemi farklı sektörlerde ve uygulamalarla karşımıza çıkmaktadır $[13,14,15,16]$.

Literatürden de görüldüğü gibi bulanık mantığın risk analiz yöntemleri ile entegre edildiği pek çok çalışma bulunmaktadır. Özellikle bulanık mantık temelli HTEA yöntemi ile yapılan çalışmalar yapılması olası diğer bulanık mantık temelli risk analiz yöntemlerine temel sağlamaktadır. Literatür incelemesi sonucunda Fine - Kinney risk analiz yöntemi ile bulanık mantığın entegre edildiği bir çalışmaya rastlanmamıştır. Bu çalışmada Fine - Kinney risk analiz yöntemi parametreleri bulanıklaştırılarak karar kuralları oluşturulmuştur. Böylece Fine - Kinney risk analiz yönteminin parametrelerinin puanlandırılması sırasında karşılaşılan belirsizlik ortadan kaldırılmaya çalışılarak klasik yöntem ile bulanık mantık temelli yöntem bir uygulama çalışması ile karşılaştırılarak sonuçlar incelenmiştir.

\section{FİNE - KİNNEY RİSK ANALİZ YÖNTEMİ}

Fine-Kinney metodu, risklerin derecelendirilmesinde, derecelendirme sonuçlarına göre hangi işlere öncelik verilmesi ve kaynakların öncelikle nereye aktarılması konularında kullanılan bir tekniktir [17]. 1976 yılında G.F. Kinney and A.D Wiruth tarafindan geliştirilen yöntem inşaat ve çimento sektöründe yaygın olarak kullanılmaktadır. Nicel risk analiz yöntemi olan Fine - Kinney risk analizinde olasılık $(\mathrm{O})$, frekans $(\mathrm{F})$ ve şiddet (Ş) olmak üzere üç parametre bulunmakta ve tehlikelerin risk puanı/skoru bu üç parametrenin çarpımından oluşmaktadır. Elde edilen risk puanı; kabul edilebilir risk, olası risk, önemli risk, yüksek risk ve çok yüksek risk olmak üzere 5 sınıfa ayrılmıştır.

Fine - Kinney risk analizinde kullanılan olasılık skalası Tablo 1'de; frekans skalası Tablo 2'de; şiddet skalası Tablo 3'de ve risk puanına ait sınıflandırma skalası Tablo 4'de verilmiştir.

Kinney ve Wiruth, 1976 yllında yapmış olduğu çalışmada 10' luk skala ile referans noktası olarak belirlediği 'Yüksek Kuvvetli İhtimal' i daha önceden meydana gelmiş, tekrarı mümkün olan ve gelecekte olacak olan olay olarak tanımlamış ve bu değere 10 atamıştır. Diğer bir referans noktası olan 'Oldukça Düşük İhtimal' i değerine 1' i atamıştır. Olasılık skalasının tabanını oluşturan 'Neredeyse İmkansız' olasıllı̆̆ının değerine de 0.1 değerini vererek ara değerler ise deneyime bağlı olarak azalan değerler olarak skalayı oluşturmuşlardır.

Tablo 1: Fine-Kinney Olasilık Skalası [18].

\begin{tabular}{lc}
\hline Olasılık & DEĞER \\
\hline$* * *$ Yüksek Kuvvetli İhtimal & 10 \\
Kuvvetli İhtimal & 6 \\
Seyrek Ancak Muhtemel & 3 \\
$* * *$ Oldukça Düşük İhtimal & 1 \\
Zayıf Ihtimal & 0.5 \\
Pratik Olarak İmkansız & 0.2 \\
$* * *$ Neredeyse İmkansız & 0.1 \\
\hline
\end{tabular}

Kinney ve Wiruth, yine aynı çalışmasında frekans değerleri için de bir skala tablosu oluşturmuşlardır. Frekans skalasındaki referans değerleri olasılık skalasında olduğu gibi 10 ve 1 değerleridir. Frekans tablosunda riskler saatlik, günlük, yıllık gibi zaman bazında meydana gelme sıklıklarına göre sınıflandırılmışıtır. Tablo 2'de de görüldüğü gibi belirlenen riskin frekansı 'saatlik' ise riskin 'sürekli' oluştuğu kabul edilmekte ve risk değerinin oluşmasında kullanılan frekans değeri tablodaki en yüksek değer olan 10, en düşük değer 1 , orta değer ise 3 olarak belirlenmiştir.

Tablo 2: Fine-Kinney Frekans Skalası [18]

\begin{tabular}{lc}
\hline FREKANS & DEĞER \\
\hline$* * *$ Sürekli ( Saatlik) & 10 \\
Sıklıkla (Günlük) & 6 \\
Ara Sıra (Haftalık) & 3 \\
Nadir (Aylık) & 2 \\
$* * *$ Seyrek (Yıllık) & 1 \\
Oldukça Seyrek (Yılda belki 1) & 0.5 \\
\hline
\end{tabular}

Risk puanın hesaplanmasında üçüncü çarpan olan şiddet için hazırlanan skala tablosunda risk sonucunda oluşan maliyet ve hasar miktarı dikkate alınmaktadır. Bu hesaplama sonucunda elde edilen şiddet skala tablosu Tablo 3'de verilmiştir. Burada oluşturulan skalada şiddetin oluşturacağı maliyet veya ölüm oranı dikkate alınarak puanlama yapilmıştır.

Tablo 3: Fine-Kinney Siddet Skalası [18]

\begin{tabular}{|c|c|}
\hline ŞIDDET & DEĞER \\
\hline $\begin{array}{l}* * * \text { Facia (>10^7\$ zarar)-birden fazla ölümlü kaza(sel/ } \\
\text { yangın/deprem/hortum) }\end{array}$ & 100 \\
\hline Felaket (>10^6\$ zarar)- öldürücü kaza & 40 \\
\hline Çok ciddi ( >10^5\$ zarar)-yaralanma/iş kaybı & 15 \\
\hline Ciddi (>10^4\$ zarar)/ yaralanma/ dış ilk yardım & 7 \\
\hline Önemli (>10^3\$ zarar)- dahili ilk yardım/yaralanma & 3 \\
\hline *** Fark Edilebilir (>10^2\$ zarar) ucuz atlatma/kesik/ çizik & 1 \\
\hline
\end{tabular}


Belirlenen riske bağlı olarak olasılık, frekans ve şiddet değerleri ilgili tablolarından elde edilmekte ve üç parametre çarpılarak risk skoru belirlenmektedir. Elde edilen risk skorları Tablo 4'e göre sınıflandırılmaktadır.

Tablo 4: Fine-Kinney Risk Skalası [18].

\begin{tabular}{ll}
\hline Risk Skoru & Risk durumu \\
\hline $\mathbf{R}<\mathbf{2 0}$ & Kabul Edilebilir -Acil Eylem gerekmeyebilir \\
$\mathbf{2 0}<\mathbf{R}<\mathbf{7 0}$ & Olası Risk- Eylem Planına alınmalıdır \\
$\mathbf{7 0 < R < 2 0 0}$ & Önemli Risk-Dikkatle İzlenmeli \\
$\mathbf{2 0 0 < R < 4 0 0}$ & Yüksek Risk- Kısa vadeli eylem planına alınmalı \\
$\mathbf{R}>\mathbf{4 0 0}$ & Çok Yüksek Risk- Derhal Tedbir alınmalı \\
\hline
\end{tabular}

\section{BULANIK FİNE - KİNNEY YAKLAŞIMI}

Fine - Kinney risk analiz yönteminde parametrelerinin puanlandırılması sırasında karşılaşılan belirsizliği ortadan kaldırmak için olasılık, frekans ve şiddet parametreleri bulanıklaştırılırmış ve karar kuralları oluşturulmuştur. Şekil 1'de görüldüğü gibi Bulanık Fine - Kinney yaklaşımında olasılık, frekans ve şiddet parametreleri girdi; Risk Skoru değeri de çıktı olarak alınmıştır. Üçgen üyelik fonksiyonlarına sahip girdiler ve çıktı için oluşturulan karar kurallarında "mamdani min max" metodu kullanılmış olup Matlab Fuzzy Logic Designer programında kodlanmıştır.

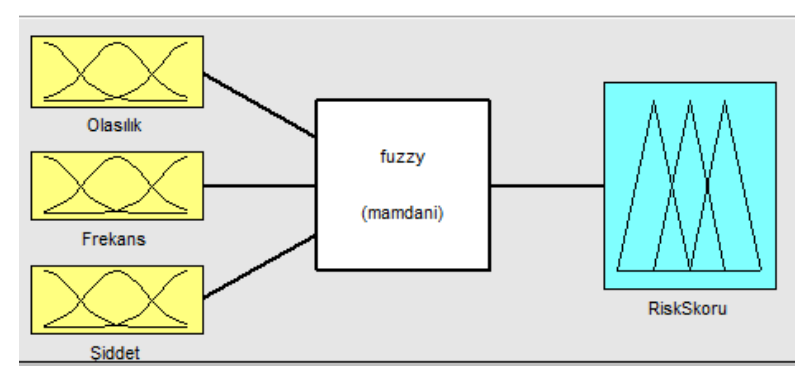

Şekil 1: Bulanık Fine - Kinney tasarımı

Olasılık, frekans ve şiddet girdileri ve Risk Skoru çıtısıs için oluşturulan üçgen üyelik fonksiyonları sırasıyla Tablo 5, Tablo 6, Tablo 7 ve Tablo 8'de verilmiştir. Üyelik fonksiyonları oluşturulurken parametreye ait skala tablosunda bulunan bir alt ve bir üst değerden faydalanılmıştır. Örneğin Tablo 5'de bulunan olasılık parametresinde yer alan "Kuvvetli İhtimal" bulanı klaştırılırken "Yüksek Kuvvetli İhtimal" e ait "10" değeri ve "Seyrek Ancak Muhtemel" e ait " 3 " değeri üyelik fonksiyonuna dahil edilerek "Kuvvetli İhtimal” in üyelik fonksiyonu $(3,6,10)$ olarak belirlenmiştir. Parametrelere ait tablolarda bulunan en alt seviyede üçgen üyelik fonksiyonunda bulunan alt değer en alt seviyedeki değerle aynı alınmıştır. Örneğin Tablo 5'de bulu- nan olasılık parametresinde "Neredeyse İmkansı" a ait üyelik fonksiyonu $(0,0.1,0.2)$ olarak tanımlanmıştır. Parametrelere ait tablolarda bulunan en üst seviyede üçgen üyelik fonksiyonunda bulunan üst değer, en üst seviyedeki değerle aynı alınmıştır. Örneğin Tablo 5'de bulunan olasılık parametresinde "Yüksek Kuvvetli İhtimal" e ait üyelik fonksiyonu $(6,10,10)$ olarak tanımlanmıştır.

Tablo 5: Olasılık parametresi için bulanık ölçek

\begin{tabular}{lcc}
\hline \multicolumn{1}{c}{ Olasılık } & $\begin{array}{c}\text { Fine-Kinney } \\
\text { Değeri }\end{array}$ & $\begin{array}{c}\text { Bulanık Fine- } \\
\text { Kinney Üçgen } \\
\text { Üyelik Fonksiyonu } \\
\text { Aralıkları }\end{array}$ \\
\hline ***Yüksek Kuvvetli Ihtimal & 10 & $(6,10,10)$ \\
Kuvvetli ihtimal & 6 & $(3,6,10)$ \\
Seyrek Ancak Muhtemel & 3 & $(1,3,6)$ \\
***Oldukça Düsüuk intimal & 1 & $(0.5,1,3)$ \\
Zayıf Ihtimal & 0.5 & $(0.2,0.5,1)$ \\
Pratik Olarak Imkansız & 0.2 & $(0.1,0.2,0.5)$ \\
$* * *$ Neredeyse Imkansız & 0.1 & $(0,0.1,0.2)$ \\
\hline
\end{tabular}

Tablo 6: Frekans parametresi için bulanık ölçek

\begin{tabular}{lcc}
\hline \multicolumn{1}{c}{ Frequency } & $\begin{array}{c}\text { Fine-Kinney } \\
\text { Değeri }\end{array}$ & $\begin{array}{c}\text { Bulanık Fine- } \\
\text { Kinney Üçgen } \\
\text { Üyelik } \\
\text { Fonksiyonu } \\
\text { Aralıkları }\end{array}$ \\
\hline ***Sürekli ( Saatlik) & 10 & $(6,10,10)$ \\
Sıklıkla (Günlük) & 6 & $(3,6,10)$ \\
Ara Sıra (Haftalık) & 3 & $(2,3,6)$ \\
Nadir (Aylık) & 2 & $(1,2,3)$ \\
$* * *$ Seyrek (Yıllık) & 1 & $(0.5,1,2)$ \\
Oldukça Seyrek (Yılda belki 1) & 0.5 & $(0,0.5,1)$ \\
\hline
\end{tabular}

Tablo 7: Şiddet parametresi için bulanık ölçek

\begin{tabular}{|c|c|c|}
\hline Şiddet & $\begin{array}{c}\text { Fine- } \\
\text { Kinney } \\
\text { Değeri }\end{array}$ & $\begin{array}{c}\text { Bulanık Fine- } \\
\text { Kinney Üçgen } \\
\text { Üyelik } \\
\text { Fonksiyonu } \\
\text { Aralıkları }\end{array}$ \\
\hline $\begin{array}{l}\text { ***Facia (>10^7\$ zarar)-birden fazla } \\
\text { ölümlü kaza(sel/yangın/deprem/hortum) }\end{array}$ & 100 & $(40,100,100)$ \\
\hline $\begin{array}{l}\text { Felaket (>10^ } 6 \$ \text { zarar)- öldürücü } \\
\text { kaza }\end{array}$ & 40 & $(15,40,100)$ \\
\hline $\begin{array}{l}\text { Çok ciddi ( >10^5\$ zarar)-yaralanma/ } \\
\text { iş kaybı }\end{array}$ & 15 & $(7,15,40)$ \\
\hline $\begin{array}{l}\text { Ciddi (>10^4\$ zarar)/ yaralanma/ dış } \\
\text { ilk yardım }\end{array}$ & 7 & $(3,7,15)$ \\
\hline $\begin{array}{l}\text { Önemli (>10^3\$ zarar)- dahili ilk } \\
\text { yardım/yaralanma }\end{array}$ & 3 & $(1,3,7)$ \\
\hline $\begin{array}{l}* * * \text { Fark Edilebilir (>10^2\$ zarar) } \\
\text { ucuz atlatma/kesik/ çizik }\end{array}$ & 1 & $(0,1,3)$ \\
\hline
\end{tabular}


Tablo 8: Risk Skoru için bulanık ölçek

\begin{tabular}{|c|c|c|}
\hline Risk Skoru & Risk durumu & $\begin{array}{l}\text { Bulanık Fine- } \\
\text { Kinney Üçgen } \\
\text { Üyelik } \\
\text { Fonksiyonu } \\
\text { Aralıkları }\end{array}$ \\
\hline$R<20$ & $\begin{array}{l}\text { Kabul Edilebilir-Acil Eylem } \\
\text { gerekmeyebilir }\end{array}$ & $(0,20,70)$ \\
\hline $20<R<70$ & $\begin{array}{l}\text { Olası Risk- Eylem Planına } \\
\text { alınmalıdır }\end{array}$ & $(20,70,200)$ \\
\hline $70<R<200$ & Önemli Risk-Dikkatle İzlenmeli & $(70,200,300)$ \\
\hline $200<R<400$ & $\begin{array}{l}\text { Yüksek Risk- Kısa vadeli eylem } \\
\text { planına alınmalı }\end{array}$ & $(200,300,400)$ \\
\hline$R>400$ & $\begin{array}{l}\text { Çok Yüksek Risk- Derhal Tedbir } \\
\text { alınmalı }\end{array}$ & $(300,400,400)$ \\
\hline
\end{tabular}

Olasılık, frekans ve şiddet girdileri ve Risk Skoru çıktısına ait üçgen üyelik fonksiyonlarına ait bulanık diyagramları sırasıyla Şekil 2, Şekil 3, Şekil 4 ve Şekil 5'de verilmiştir.

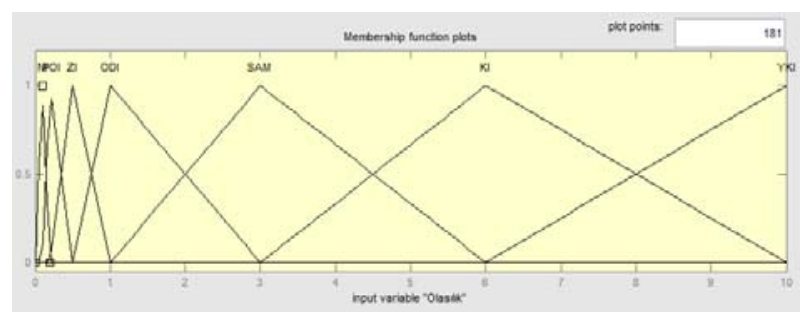

Şekil 2: Olasılık parametresi bulanık diyagramı

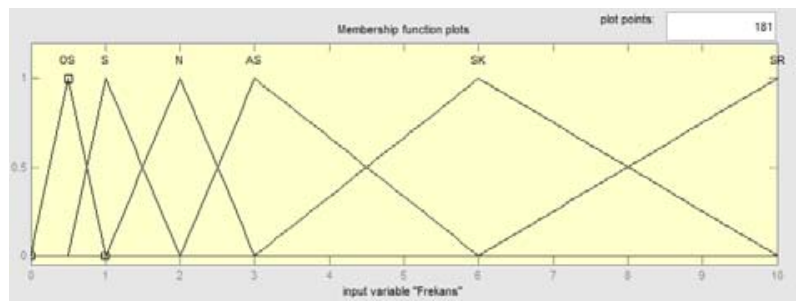

Şekil 3: Frekans parametresi bulanık diyagramı

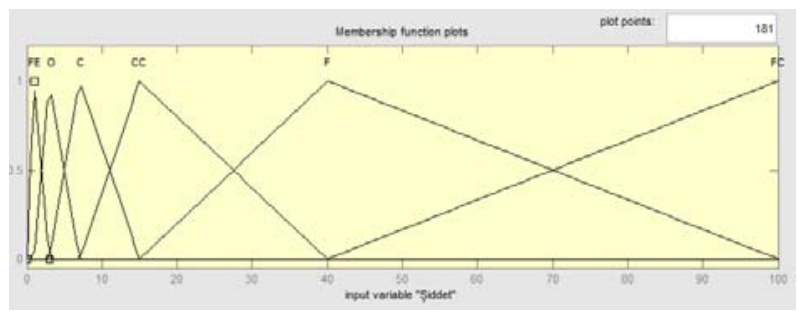

Şekil 4: Şiddet parametresi bulanık diyagramı

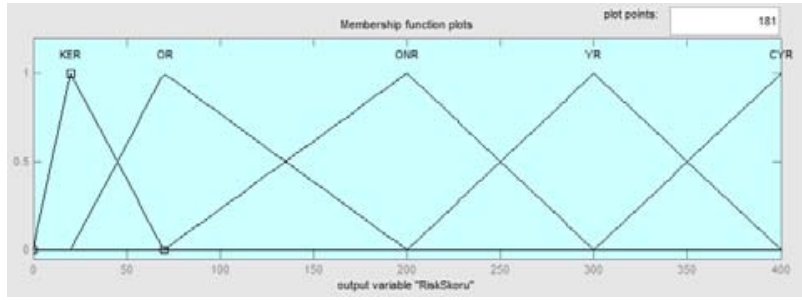

Şekil 5: Risk Skoru bulanık diyagramı

\section{UYGULAMA ÇALIŞMASI}

Çalışmanın bu aşamasında inşaat sektöründe hizmet veren orta ölçekli bir firmanın yapımını üstlendiği bir yapı merkezi inşaatında karşılaşılan ve elde edilen riskler uygulama örneği olarak belirlenmiştir.

Yapı merkezi inşaatında uygulanan risk analizi için ilk adımda tehlikeler uzmanlarla birlikte saptanarak klasik Fine - Kinney yöntemi ile tehlikelerin risk puanları ve bu puanların karşılık geldiği risk seviyeleri belirlenmiştir. Daha sonra aynı uygulama çalışması geliştirilen bulanık Fine Kinney yöntemi ile tekrar hesaplanmış ve sonuçlar karşılaştırılmıştır.

\section{A. Fine - Kinney Risk Analiz Uygulaması}

Tablo 9'da yapılan risk analizi sonucunda belirlenen tehlikeler, tehlikelerin ait olduğu süreçler, her bir tehlike için Fine - Kinney parametre (olasılık, frekans ve şiddet) değerleri, risk skorları, risk skoru seviyeleri ve risk skoru seviyelerinin açıklamaları verilmiştir. Belirlenen uygulama çalışmasında 8 ayrı sürece bağlı 10 tehlike tespit edilmiştir. Her bir tehlikeye uzmanlar ile birlikte ayrıntılı ve dikkatli bir şekilde olasılık, frekans ve şiddet değerleri verilmiş ve risk skorları hesaplanmıştır.

Tablo 9'da görüldüğü gibi risk analizi sonucunda;

- 1. ve 9. tehlikelerin sırasiyla 45 ve 21 puanları ile $(20<\mathrm{RS}<70) 2$. Risk seviyesinde olduğu ve bu tehlikelerin olası riskler olduğu ve eylem planına alınmaları gerektiği,

- 2., 6., 8. ve 10. tehlikelerin sirasiyla $120,90,135$ ve 135 puanlar1 ile $(70<\mathrm{RS}<200) 3$. Risk seviyesinde olduğu ve bu tehlikelerin önemli riskler olup dikkatle izlenmesi gerektiği,

- 3., 4., 5. ve 7. tehlikelerin sirasiyla 360, 270, 360 ve 360 puanları ile $(200<\mathrm{RS}<400)$ 4. Risk seviyesinde olduğu ve bu tehlikelerin yüksek riskli olduğu dolayısıyla kısa vadeli eylem planına alınmaları,

Yapılan risk analizi sonucuna göre 3., 4., 5. ve 7. numaralı tehlikelere öncelik verilerek mümkünse ortadan 
Tablo 9: Fine - Kinney Risk Analizi

\begin{tabular}{|c|l|c|c|c|c|c|l|}
\hline Sıra & \multicolumn{1}{|c|}{ Tehlike } & O & F & Ş & RS & $\begin{array}{c}\text { RS } \\
\text { Seviyesi }\end{array}$ & \multicolumn{1}{|c|}{ Risk Skoru Açıklaması } \\
\hline 1 & $\begin{array}{l}\text { Yumuşak zeminden dolayı iş makinala- } \\
\text { rının batması/devrilmesi }\end{array}$ & 1 & 3 & 15 & 45 & 2 & Olası Risk- Eylem Planına alınmalıdır \\
\hline 2 & $\begin{array}{l}\text { Eğimli bölgelerde damper kaldırılması- } \\
\text { na bağlı kamyon devrilmesi }\end{array}$ & 1 & 3 & 40 & 120 & 3 & Önemli Risk-Dikkatle İlenmeli \\
\hline 3 & Kamyonlarda fren patlaması & 3 & 3 & 40 & 360 & 4 & $\begin{array}{l}\text { Yüksek Risk- Kısa vadeli eylem planına } \\
\text { alınmalı }\end{array}$ \\
\hline 4 & $\begin{array}{l}\text { Vinçle taşınan malzemelerin vinçten } \\
\text { düşmesi }\end{array}$ & 3 & 6 & 15 & 270 & 4 & $\begin{array}{l}\text { Yüksek Risk- Kısa vadeli eylem planına } \\
\text { alınmalı }\end{array}$ \\
\hline 5 & $\begin{array}{l}\text { Vinçle taşınan malzemelerin salınım } \\
\text { sonucu operatöre çarpması }\end{array}$ & 3 & 3 & 40 & 360 & 4 & $\begin{array}{l}\text { Yüksek Risk- Kısa vadeli eylem planına } \\
\text { alınmalı }\end{array}$ \\
\hline 6 & $\begin{array}{l}\text { Hasarı/ekli kablo kullanımına bağlı } \\
\text { kazalar }\end{array}$ & 3 & 2 & 15 & 90 & 3 & Önemli Risk-Dikkatle İlenmeli \\
\hline 7 & $\begin{array}{l}\text { Beton araçlarının (pompa ve mikserler) } \\
\text { hız yapması }\end{array}$ & 3 & 3 & 40 & 360 & 4 & $\begin{array}{l}\text { Yüksek Risk- Kısa vadeli eylem planına } \\
\text { alınmalı }\end{array}$ \\
\hline 8 & $\begin{array}{l}\text { İş makinaları ve/veya kamyonlarına } \\
\text { yeterli mesafede durulmaması }\end{array}$ & 3 & 3 & 15 & 135 & 3 & Önemli Risk-Dikkatle İzlenmeli \\
\hline 9 & $\begin{array}{l}\text { Boya işlerinde kullanılan kimyasal } \\
\text { maddeler }\end{array}$ & 1 & 3 & 7 & 21 & 2 & Olası Risk- Eylem Planına alınmalıdır \\
\hline 10 & $\begin{array}{l}\text { Elektrik kaynağına topraklama yapı- } \\
\text { maması }\end{array}$ & 3 & 3 & 15 & 135 & 3 & Önemli Risk-Dikkatle İlenmeli \\
\hline
\end{tabular}

*P: Olasılık F: Frekans Ş:Şiddet RS: Risk Skoru

kaldırılması eğer değilse tehlikelerin Risk Skoru değerlerinin azaltılması için önlemler alınması gerektiği sonucu ortaya çıkarılmıştır. Yüksek Risk sınıfında yer alan bu tehlikeler, kısa vadeli eylem planlarına alınarak, öncelik verilmelidirler. 2., 6., 8. ve 10 numaralı tehlikelerin ise bir alt sınıftaki risk seviyesinde olduğu görülmektedir. Bu tehlikeler "Önemli Risk" sınıfında yer almış ve dikkatle izlenmek üzere "Yüksek Risk" grubunda yer alan tehlikeler için alınacak önlemlerden sonra dikkate alınmalıdır.

Tehlikelerin Risk Skoru değeri belirlenirken olasılık, frekans ve şiddet parametrelerine verilen puanlar risk analizini yapan uzman görüşüne göre farklılık gösterebilmektedir. Örneğin 10 numaralı tehlike; Tablo 9'da yapılan risk analizi sonucunda $\mathrm{P}, \mathrm{F}$ ve Ş parametrelerinden sırasıyla aldığı 3, 3 ve 15 puanlarının çarpımından elde ettiği 135 skoru ile önemli risk sınıfında yer almaktadır. Fakat uzmanın kararsız kalması veya başka bir uzman tarafından analizin yapılması durumunda sadece bir parametreye farklı bir değer vermesi bile RS değerini ve risk sınıfını değiştirebilmektedir. Örneğin P parametresinde 3 puan yerine deneyime bağlı veya kararsızlık sonucunda 1 puan verilmesi durumunda $\left(1^{*} 3^{*} 15\right) 45$ puan ile risk sınıfı bir sınıf alta düşecektir. Bu durum ilgili tehlike için alınması gereken tedbirlerde azalmaya yol açıp bir an önce önlenmesi gereken bir tehlikenin göz ardı edilmesine sebep olabilir. Ya da 7 nu- maralı tehlike için verilen $\mathrm{P}, \mathrm{F}$ ve Ş parametre puanlarındaki birer birim artış 3, 3, 40 çarpanları yerine 3, 6, 40 çarpanlarının kullanılması, ilgili tehlikeyi 1 sınıf atlatıp "Çok Yüksek Risk” sınıfına geçirecektir. Böylesi bir tehlikeden doğan riskin bir an önce aksiyon planına dâhil edilmesi, zaman ve verimlilik açısından problemlere yol açabilecektir. $\mathrm{Bu}$ sebeple uzman görüşlerindeki farklılığı azaltarak parametrelerdeki hassasiyeti arttırmak ve belirsizliklerin ortadan kaldırılması amacıyla Fine - Kinney risk analizinde yer alan parametreler bulanıklaştırılarak kuralları oluşturulmuş ve Tablo 9'da bulunan tehlikeler Bulanık Fine - Kinney ile tekrar değerlendirilmiştir.

\section{B. Fuzzy Fine - Kinney Risk Analiz Uygulaması}

Tablo 9'da bulunan tehlikeler Bulanık Fine - Kinney ölçekleri ile değerlendirilirken olasılık parametresinde Tablo 5; frekans parametresinde Tablo 6 ve şiddet parametresinde Tablo 7'de bulunan üçgen üyelik fonksiyonları dikkate alınmıştır. Tehlikelerin Bulanık Fine - Kinney risk analiz sonuçları Tablo 10'da verilmiştir.

Bulanık Fine - Kinney Risk Analiz sonuçlarına göre 10 adet tehlike için risk skorları ilgili üçgensel üyelik fonksiyonları dikkate alınarak hesaplanmış ve risk skoru açıklamaları güncellenmiştir. Buna göre 1 ve 9 no’ lu tehlikeler "Olası Risk” seviyesinden “ Önemli Risk” seviyesine geçe- 
Tablo 10: Bulanık Fine - Kinney Risk Analiz Sonuçları

\begin{tabular}{|c|c|c|c|}
\hline Sira & Tehlike & $\begin{array}{l}\text { Bulanık Risk } \\
\text { Skoru }\end{array}$ & Risk Skoru Açıklaması \\
\hline 1 & $\begin{array}{l}\text { Yumuşak zeminden dolayı iş makinalarının batması/ } \\
\text { devrilmesi }\end{array}$ & 96,7 & Önemli Risk-Dikkatle İzlenmeli \\
\hline 2 & $\begin{array}{l}\text { Eğimli bölgelerde damper kaldırılmasına bağı kamyon dev- } \\
\text { rilmesi }\end{array}$ & 300 & $\begin{array}{c}\text { Yüksek Risk- Kısa vadeli eylem planına } \\
\text { alınmalı }\end{array}$ \\
\hline 3 & Kamyonlarda fren patlaması & 368 & $\begin{array}{c}\text { Yüksek Risk- Kısa vadeli eylem planına } \\
\text { alınmalı }\end{array}$ \\
\hline 4 & Vinçle taşınan malzemelerin vinçten düşmesi & 300 & $\begin{array}{l}\text { Yüksek Risk- Kısa vadeli eylem planına } \\
\text { alınmalı }\end{array}$ \\
\hline 5 & $\begin{array}{l}\text { Vinçle taşınan malzemelerin salınım sonucu operatöre çarp- } \\
\text { ması }\end{array}$ & 368 & $\begin{array}{c}\text { Yüksek Risk- Kısa vadeli eylem planına } \\
\text { alınmalı }\end{array}$ \\
\hline 6 & Hasarlı/ekli kablo kullanımına bağlı kazalar & 190 & Önemli Risk-Dikkatle İzlenmeli \\
\hline 7 & Beton araçlarının (pompa ve mikserler) hız yapması & 368 & $\begin{array}{c}\text { Yüksek Risk- Kısa vadeli eylem planına } \\
\text { alınmalı }\end{array}$ \\
\hline 8 & $\begin{array}{l}\text { İş makinaları ve/veya kamyonlarına yeterli mesafede durul- } \\
\text { maması }\end{array}$ & 300 & $\begin{array}{l}\text { Yüksek Risk- Kısa vadeli eylem planına } \\
\text { alınmalı }\end{array}$ \\
\hline 9 & Boya işlerinde kullanılan kimyasal maddeler & 96,7 & Önemli Risk-Dikkatle İzlenmeli \\
\hline 10 & Elektrik kaynağına topraklama yapılmaması & 300 & $\begin{array}{c}\text { Yüksek Risk- Kısa vadeli eylem planına } \\
\text { alınmalı }\end{array}$ \\
\hline
\end{tabular}

Tablo 11: Karşılaştırmalı Eylem Planı Tablosu

\begin{tabular}{|c|c|c|c|c|c|}
\hline Sira & Tehlike & KYRS & $\begin{array}{l}\text { Risk Skoru Açıkla- } \\
\text { ması }\end{array}$ & BYRS & Risk Skoru Açıklaması \\
\hline 1 & $\begin{array}{l}\text { Yumuşak zeminden dolayı iş makinalarının } \\
\text { batması/devrilmesi }\end{array}$ & 45 & $\begin{array}{l}\text { Olası Risk- Eylem } \\
\text { Planına alınmalıdır }\end{array}$ & 96,7 & $\begin{array}{l}\text { Önemli Risk-Dikkatle } \\
\text { İzlenmeli }\end{array}$ \\
\hline 2 & $\begin{array}{l}\text { Eğimli bölgelerde damper kaldırılmasına bağlı } \\
\text { kamyon devrilmesi }\end{array}$ & 120 & $\begin{array}{l}\text { Önemli Risk- } \\
\text { Dikkatle İzlenmeli }\end{array}$ & 300 & $\begin{array}{l}\text { Yüksek Risk- Kısa vadeli } \\
\text { eylem planına alınmalı }\end{array}$ \\
\hline 3 & Kamyonlarda fren patlaması & 360 & $\begin{array}{l}\text { Yüksek Risk- Kısa } \\
\text { vadeli eylem planına } \\
\text { alınmalı }\end{array}$ & 368 & $\begin{array}{l}\text { Yüksek Risk- Kısa vadeli } \\
\text { eylem planına alınmalı }\end{array}$ \\
\hline 4 & Vinçle taşınan malzemelerin vinçten düşmesi & 270 & $\begin{array}{l}\text { Yüksek Risk- Kısa } \\
\text { vadeli eylem planına } \\
\text { alınmalı }\end{array}$ & 300 & $\begin{array}{l}\text { Yüksek Risk- Kısa vadeli } \\
\text { eylem planına alınmalı }\end{array}$ \\
\hline 5 & $\begin{array}{l}\text { Vinçle taşınan malzemelerin salınım sonucu } \\
\text { operatöre çarpması }\end{array}$ & 360 & $\begin{array}{l}\text { Yüksek Risk- Kısa } \\
\text { vadeli eylem planına } \\
\text { alınmalı }\end{array}$ & 368 & $\begin{array}{l}\text { Yüksek Risk- Kısa vadeli } \\
\text { eylem planına alınmalı }\end{array}$ \\
\hline 6 & Hasarlı/ekli kablo kullanımına bağlı kazalar & 90 & $\begin{array}{l}\text { Önemli Risk-Dikkatle } \\
\text { İzlenmeli }\end{array}$ & 190 & $\begin{array}{l}\text { Önemli Risk-Dikkatle } \\
\text { İzlenmeli }\end{array}$ \\
\hline 7 & $\begin{array}{l}\text { Beton araçlarının (pompa ve mikserler) hız } \\
\text { yapması }\end{array}$ & 360 & $\begin{array}{l}\text { Yüksek Risk- Kısa } \\
\text { vadeli eylem planına } \\
\text { alınmalı }\end{array}$ & 368 & $\begin{array}{l}\text { Yüksek Risk- Kısa vadeli } \\
\text { eylem planına alınmalı }\end{array}$ \\
\hline 8 & $\begin{array}{l}\text { İş makinaları ve/veya kamyonlarına yeterli } \\
\text { mesafede durulmaması }\end{array}$ & 135 & $\begin{array}{l}\text { Önemli Risk- } \\
\text { Dikkatle İzlenmeli }\end{array}$ & 300 & $\begin{array}{l}\text { Yüksek Risk- Kısa vadeli } \\
\text { eylem planına alınmalı }\end{array}$ \\
\hline 9 & Boya işlerinde kullanılan kimyasal maddeler & 21 & $\begin{array}{l}\text { Olası Risk- Eylem } \\
\text { Planına alınmalıdır }\end{array}$ & 96,7 & $\begin{array}{l}\text { Önemli Risk-Dikkatle } \\
\text { İzlenmeli }\end{array}$ \\
\hline 10 & Elektrik kaynağına topraklama yapılmaması & 135 & $\begin{array}{l}\text { Önemli Risk- } \\
\text { Dikkatle İzlenmeli }\end{array}$ & 300 & $\begin{array}{l}\text { Yüksek Risk- Kısa vadeli } \\
\text { eylem planına alınmalı }\end{array}$ \\
\hline
\end{tabular}

* KYRS: Klasik Yöntem Risk Skoru *BYRS: Bulanık Yöntem Risk Skoru 
rek 1 sınıf atlamıştır. Bu tehlikelerin eylem planı içerisine dikkatle izlenmesi gerektiği sonucuna varılarak hassasiyetleri arttırılmıştır. 2, 8 ve 10 no'lu tehlikeler ise "Önemli" seviyesinden " "Yüksek Risk" seviyesine yükselerek kısa vadeli eylem planlarında yer alması gerektiği sonucuna varılmıştır. $\mathrm{Bu}$ tehlikelerden doğan risklerin hassasiyeti arttırılmış olup, önem kazandırılmıştır. Böylece eylem planlarına daha üst sıralardan yerleşmeleri gerektiği sonucuna varılmıştır. Bu sayede, eylem planına geç alınma ve tehlikenin önceliklendirilmemesinden doğan hatalar sebebiyle gözden kaçırma gibi sorunların önüne geçilmiştir. 3, 4, 5, 6 ve 7 numaralı tehlikelerden doğan risklerin puanlarındaki artışlar eylem planlarında alınması gereken aksiyonlarda değişiklik yaratmamaktadır. Klasik ve Bulanık Fine Kinney Yöntemleri için hazırlanan "Karşılaştırmalı Eylem Planı” Tablo 11'de sunulmuştur.

\section{SONUÇ}

İş Sağlığı ve Güvenliği çerçevesinde işletmelerde gerçekleştirilen risk değerlendirme yöntemlerinin kullanımları günümüzde sektörden sektöre farklılık göstermektedir. 4857 sayılı İş Kanunu ve sonrasında 6331 sayılı iş sağlı̆̆ı ve güvenliği kanunu ile ölçeği ne olursa olsun risk değerlendirme yapma zorunluluğu getirilen işletmeler, daha güvenilir ve doğru sonuçları uygulayabilmek ve elde etmek amacıyla uygun yöntemleri bulmaya çalışmaktadırlar. Yöntemlerin sonuçları arasında ortaya çıkan farklılıklar; uzmanların yöntemleri uygularken yetersiz kaldığı veya tereddüte düştüğü karar noktalarında gerçekleştirilen risk analizlerinde, tehlikelerin hatalı önceliklendirilmesi ve ilgili tehlikelerin yanlış sınıflandırması sonuçları ortaya çıkmaktadır.

Bu çalışmada Klasik Fine - Kinney yöntemi temelinden yola çıkarak bulanık mantık çerçevesinde yeni bir yaklaşım geliştirilmiş ve inşaat sektöründe hizmet veren orta ölçekli bir firmanın yapımını üstlendiği bir yapı merkezi inşaatında yeni oluşturulan yaklaşım uygulanarak sonuçlar karşılaştırılmıştır. Çalışmada temel olarak klasik metottaki olasılık, frekans ve şiddet ve risk skoru tablolarındaki bütün değerler için üçgen üyelik fonksiyonuna bağlı yeni değerler oluşturulmuştur. Uygulama çalışması ile birlikte bulanık risk skorları tekrar hesaplanmış ve incelenen 10 adet tehlike için risk sınıfları yeniden değerlendirilmiştir. Her iki yöntem karşılaştırıldığında 5 adet tehlikenin sınıflarının değiştiği ve sonuç olarak bu tehlikelerin risk skorlarına göre hassasiyetlerinin ve önem derecelerinin yükseldiği tespit edilmiştir. Bulanık Fine - Kinney Yöntemi sayesinde uzman görüşlerindeki farklılığı azaltarak parametrelerdeki hassasiyetler arttırılmış ve belirsizliklerin ortadan kaldırılmıştır.

Uygulama sonuçları, klasik yöntemin bazı noktalarda yetersiz kaldığını ve yeni oluşturulan yöntemlerin tehlikelerden doğan risk puanlarına hassasiyet kazandırdığını işaret etmektedir.

\section{REFERANSLAR}

[1] 4857 İş Kanunu; 6331 İş Sağlığı ve Güvenliği Kanu$\mathrm{nu}$

[2] Özkılıç, Ö. (2005). İş Sağlığı ve Güvenliği. Yönetim Sistemleri ve Risk Değerlendirme Metodolojileri, TİSK Yayınları, İstanbul.

[3] Bonfant, G., Belfanti, P., Paternoster, G., Gabrielli, D., Gaiter, A. M., Manes, M., Molino, A., Pellu, V., Ponzetti, C., Farina, M., Nebiolo, P. E. (2010). Clinical risk analysis with failure mode and effect analysis (FMEA) model in a dialysis unit. Journal of Nephrology, 23(1), 111-8.

[4] de la O Herrera, M. A., Luna, A. S., da Costa, A. C. A., \& Lemes, E. M. B. (2015). A structural approach to the HAZOP-Hazard and operability technique in the biopharmaceutical industry. Journal of Loss Prevention in the Process Industries, 35, 1-11.

[5] Şenel, B., \& Şenel, M. (2013). Risk Analizi: Türkiye'de Gerçekleşen Trafik Kazaları Üzerine Hata Ağacı Analizi Uygulaması. Anadolu University Journal of Social Sciences, 13(3), 65-83.

[6] Topaloğlu, G., Koç, A., Yağlı, H., \& Öztürk, N. A. (2015). Yüksek Firinlarin İşletilmesinde Risk Değerlendirilmesinin Yapilmasi ve Geliştirilmesi. Engineer \& The Machinery Magazine, (661).

[7] Ceylan, H., \& Başhelvacı, V. S. (2011). Risk Değerlendirme Tablosu Yöntemi İle Risk Analizi: Bir Uygulama. International Journal of Engineering Research and Development, 3(2), 25-33.

[8] Köse, E., Dinçer, A. C., \& Durukanoğlu, H. F. (1998). Risk assessment of fishing vessels. Turkish Journal of Engineering and Environmental Sciences, 22(5), 417-428.

[9] Koltan, A., Orhon, H. Y., Yılmaz, S., Altay, M., Y1lmaz, S., \& Çay, İ. (2010). Risk Değerlendirmede Kullanilan L Tipi Karar Matrisi Yönteminin İşçi Sağliğina Uygunluğunun Değerlendirilmesi, Mesleki Sağlık ve Güvenlik Dergisi (MSG), 10(38).

[10] Kumru, M. \& Kumru, P. Y. (2010). Hastanelerde satın alma sürecinin iyileştirilmesi: Bir örnek uygula- 
ma, II. Uluslararası Sağlıkta Performans ve Kalite Kongresi Bildiriler Kitabı, 171- 183.

[11] Kahraman, C., Kaya, İ., \& Şenvar, Ö. (2013). Healthcare failure mode and effects analysis under fuzziness. Human and Ecological Risk Assessment: An International Journal, 19(2), 538-552.

[12] Özfırat, P. M. (2014). Bulanik Önceliklendirme Metodu Ve Hata Türü Ve Etkileri Analizini Birleştiren Yeni Bir Risk Analizi Yöntemi. Gazi Üniversitesi Mühendislik-Mimarlık Fakültesi Dergisi, 29(4).

[13] Monika K., \& Roland J. (2008). Critically assessment for FMEA analysis using fuzzy logic. JApplied Math 1(1):260-71.

[14] Xu, K., Tang, L. C., Xie, M., Ho, S. L., \& Zhu, M. L. (2002). Fuzzy assessment of FMEA for engine systems. Reliability Engineering \& System Safety, 75 (1), 17-29.

[15] Kutlu, A. C., \& Ekmekcioglu M. (2012). Fuzzy failure modes and effects analysis by using fuzzy TOPSISbased fuzzy AHP. Expert Systems with Applications 39(1):61-7.

[16] Chang, K. H., \& Cheng, C. H. (2010). A risk assessment methodology using intuitionistic fuzzy set in FMEA. Internat J Systems Sci 41(12):1457-71.

[17] Özgür, M. (2013) Metal Sektöründe Risk Analizi Uygulaması, ÇSGB, İş Müfettişliği Yardımcılığı Etüdü, İzmir.

[18] Kinney, G. F., \& Wiruth, A. D. (1976). Practical Risk Analysis For Safety Management (No. NWCTP-5865). Naval Weapons Center China Lake CA. 
